\title{
Growth rates and age at adult size of loggerhead sea turtles (Caretta caretta) in the Mediterranean Sea, estimated through capture-mark-recapture records
}

\author{
PAOLO CASALE ${ }^{1}$, ANTONIOS D. MAZARIS ${ }^{2}$, DANIELA FREGGI ${ }^{3}$, \\ CAROLA VALLINI ${ }^{4}$ and ROBERTO ARGANO ${ }^{1}$ \\ ${ }^{1}$ Department of Animal and Human Biology, University of Rome 1 'La Sapienza', Viale dell’Università 32, 00185 Roma, \\ Italy. E-mail: paolo.casale@tiscali.it \\ ${ }^{2}$ Department of Ecology, School of Biology, Aristotle University, U.P. Box 119, 54124, Thessaloniki, Greece. \\ ${ }^{3}$ Sea Turtle Rescue Centre WWF Italy, CP 92010 Lampedusa, Italy. \\ ${ }^{4}$ A.R.C.H.E', via Mulinetto, 40/A 44100 Ferrara, Italy.
}

SUMMARY: Growth rates of the juvenile phase of loggerhead turtles (Caretta caretta) were estimated for the first time in the Mediterranean Sea from capture-mark-recapture records. Thirty-eight turtles were released from Italian coasts and re-encountered after 1.0-10.9 years in the period 1986-2007. Their mean CCL (curved carapace length) ranged from 32.5 to $82.0 \mathrm{~cm}$ and they showed variable growth rates, ranging from 0 to $5.97 \mathrm{~cm} / \mathrm{yr}$ (mean: 2.5). The association between annual growth rate and three covariates (mean year, mean size and time interval) was investigated through a non-parametric modelling approach. Only mean size showed a clear effect on growth rate, described by a monotonic declining curve. Variability indicates that factors not included in the model, probably individual-related ones, have an important effect on growth rates. Based on the monotonic decreasing growth function which indicates no growth spurt, a von Bertalanffy growth function was used to estimate the time required by turtles to grow within the observed size range. The results indicate that turtles would take 16-28 years to reach $66.5-84.7 \mathrm{~cm} \mathrm{CCL}$, the average nesting female sizes observed at the most important Mediterranean nesting sites, which can be considered an approximation of the size at maturity.

Keywords: loggerhead sea turtle, growth rate, capture-mark-recapture, Mediterranean.

RESUMEN: TASAS DE CRECIMIENTO Y TALla A LA EDAD ADUlta DE LA TORTUGa Boba (CARETTA CARETTA) EN EL MAR Mediterráneo, estimada a través de Registros de CAPTURA-MARCAJE-RECAPTURA. - A partir de registros de capturamarcaje-recaptura, se estimaron por primera vez en el Mediterráneo las tasas de crecimiento de las fases juveniles de la tortuga boba (Caretta caretta). Se liberaron treinta y ocho tortugas a partir de la costa italiana y se reencontraron después de 1.0-10.9 años en el periodo 1986-2007. El promedio de LCC (longitud curvada del caparazón) varió de 32.5 a $82.0 \mathrm{~cm}$ y se observaron tasas de crecimiento variables, de 0 a $5.97 \mathrm{~cm} /$ año (promedio: 2.5 ). La asociación entre la tasa de crecimiento anual y tres covariables (año promedio, talla promedio e intervalo de tiempo) se investigó a través de un modelo no-paramétrico. Solamente la talla media mostró un claro efecto en la tasa de crecimiento, descrito por una curva monotónica descendente. La variabilidad observada indica que factores no incluidos en el modelo, probablemente relacionados con el individuo, tienen un importante efecto en las tasas de crecimiento. En base a la función de crecimiento monotónicamente decreciente que indica que no hay esfuerzo en el crecimiento, se uso una función de crecimiento de von Bertalanffy para estimar el tiempo requerido por las tortugas para crecer dentro del rango de tallas observado. Los resultados indican que las tortugas necesitarán de 16-28 años para alcanzar 66.5-84.7 cm LCC, la talla promedio de anidación observada en las más importantes áreas de anidación del Mediterráneo, lo que puede ser considerado como una aproximación a la talla de madurez.

Palabras clave: tortuga boba, tasa de crecimiento, captura marcaje recaptura, Mediterráneo. 


\section{INTRODUCTION}

Sea turtle population dynamics is still poorly known, and this makes it difficult to understand how the populations of these threatened species respond to human impacts and thus to plan suitable conservation strategies. In this respect, assessing growth rates is fundamental in order to estimate the duration of the different life history stages as well as the age at maturity (e.g. Heppell et al., 2003a; Mazaris et al., 2005). In turn, these parameters are necessary to build realistic models of turtle population dynamics that can suggest how a sea turtle population may respond to specific threats (e.g. by-catch) acting on a specific life history stage (e.g. small turtles feeding upon pelagic preys) and how long a specific conservation measure (e.g. longline fishery regulation) may take to produce a population recovery (e.g. see Heppell et al., 2003b). This is fundamental for choosing among different conservation strategies.

Sea turtles may show great variability of growth rates, even within the same species, which may be caused by genetic, sexual, and/or environmental factors (see Heppell et al., 2003a).

For instance, Bjorndal and Bolten (1988) reported growth rates of loggerhead turtles in the Bahamas being much higher than those of the same size class in the North Atlantic (Bjorndal et al., 2000a).

For this reason, growth rates of a certain population/area cannot be assumed to be necessarily the same as those of another one and it is necessary to obtain specific estimates for different populations and even at different foraging grounds frequented by the same population.

Loggerhead sea turtles (Caretta caretta) are listed as endangered in the IUCN Red List of Threatened Species and they represent the most common sea turtle species in the Mediterranean, widespread all over the basin (Margaritoulis et al., 2003). Although high numbers of Atlantic turtles enter the Mediterranean (Laurent et al., 1998; Carreras et al., 2006a; Casale et al., 2008), genetic markers indicate that this population is relatively isolated from the Atlantic ones (Carreras et al., 2006b) and one of its most distinctive characteristics is the significantly smaller adult size in comparison with other populations around the world (Dodd, 1988; Margaritoulis et al., 2003). This may be due to an earlier sexual maturation, to slower growth, or to both. Unfortunately, growth rate data that could clarify this question are not available so far for the Mediterranean. This lack of knowledge about the duration of the immature life stage of the Mediterranean population hinders the development of population dynamics models that can help to understand the impact of the anthropogenic threats occurring in the basin. The most important one is the mortality induced by fishing gear, with different fishing gear affecting turtles of different sizes (Margaritoulis et al., 2003; Casale, 2008). Assessing the duration of life stages can therefore help us to understand the impact of different fishing gear.

Estimating growth rates is not a simple task, because collecting data from a suitable number of individuals of an elusive marine species like sea turtles is very difficult. Multiple measurements of the same individual at time intervals, through a capture-markrecapture (CMR) approach, is the most obvious method for obtaining such data. However, turtles are highly vagile and relatively slow growing, so intensive and long CMR programmes are required.

The first tagging programme of turtles at sea in the Mediterranean was launched in 1981 in Italy, and was specifically focused on loggerhead turtle juveniles, providing an indication on their movements and feeding areas (Argano et al., 1992; Casale et al., 2007). Italy is particularly suitable for CMR studies because it is a large peninsula protruding in the centre of the Mediterranean, enhancing both tagging opportunities and chances of tag returns.

This study aims to provide for the first time an estimation of growth rates in a wide range of sizes and ages at maturity for Mediterranean loggerhead turtles by analysing CMR data from three Italian sea turtle tagging projects through a non-parametric modelling approach and by using a classic somatic growth model.

\section{MATERIALS AND METHODS}

\section{Data collection}

In order to minimise possible sources of error, 38 loggerhead turtle capture-mark-recapture records were selected according to two criteria: (i) only turtles with a time interval between release and reencounter longer than one year, in order to reduce biases due to possible differences in growth rates among seasons of the year (Chaloupka and Musick, 1997; Bjorndal et al., 2000b); (ii) only turtles measured either by the same person both at release and re-encounter or by persons using exactly the same 
measurement method, in order to reduce possible measurement errors. Most of the turtles were immature, so without sexual dimorphism, and sex was not determined.

Turtles were tagged with monel or inconel tags (styles 49 or 681, National Band and Tag, Kentucky, USA) attached to one or both front flippers, and their curved carapace length notch-to-tip (CCLn-t; Bolten, 1999) was measured.

Turtles were originally captured by fishing gears, found stranded, or gathered while floating at sea, and they were released and re-encountered around Italy in the period 1986-2007. Thirty-six records were from three tagging programmes (Univ. of Rome, WWF, Arché) and two additional records were included from two other tagging programs (Bojan Lazar, pers. comm.; Gregorio De Metrio, pers. comm.).

Absolute growth rates $(\mathrm{cm} / \mathrm{yr})$ were calculated for each turtle as (CCL final - CCL initial)/(days/365).

\section{Data analysis}

Given the objective of this study, i.e. growth rate and age at size, we firstly investigated the relation between size and growth as well as any detectable effects of possible covariates on the growth function. Mean size (the arithmetic mean between release and re-encounter sizes) was included in the model to describe size-specific growth, because it was assumed to be more representative of the size class/time interval for which the growth rate was calculated than size at release or at re-encounter, which are at the extremes of the range. In fact, mean size is considered as an suitable metric for size-specific growth (e.g. Chaloupka and Limpus, 1997), assuming a linear growth function through the time interval between release and re-encounter. However, this is seldom the case, especially with long time intervals. Therefore, to account for possible biases associated with this parameter, time interval was included in the model as an additional covariate (e.g. Seminoff et al., 2002). Regarding other covariates, growth is a time-dependent function affected by three time effects: age, year (environment) and cohort (genetic, environment). Unfortunately, capture-mark-recapture studies usually lack information about age and cohort, and we used mean calendar year (the mean year between capture and re-encounter years) as a covariate accounting for the time effect, as shown by other studies (see also Limpus and Chaloupka, 1997; Bjorndal et al., 2000b; Balazs and Chaloupka, 2004).
Mean year was preferred to release or re-encounter year for the reasons explained above for the mean size. This covariate accounts for the effects of environmental variation in the growth process, although it cannot be clearly distinguished from age and cohort effects and its effects could be masked by small sample size and long time intervals. In total, three covariates were considered: mean year, mean size, and time interval between release and re-encounter.

Data were analysed through a non-parametric generalized additive modelling approach (GAM; Hastie and Tibshirani, 1990), which enables robust analysis of regression models with non-normal error terms and non-linear covariate functional forms, and has been used by previous studies on sea turtle growth (Limpus and Chaloupka, 1997; Balazs and Chaloupka, 2004; Chaloupka et al., 2004; Chaloupka and Limpus, 1997). The model examined the nonlinear associations between the dependent variable (annual growth rate) and the three growth predictor variables (mean year, mean size and recapture interval) and comprised an identity link function, a robust quasi-likelihood error function and flexible cubic smoothing splines. Link functions were used to connect the dependent variable with a combination of predictor variables, and thus to model responses of the dependent variable related to the predictors. We used an identity link function since no other transformation was considered necessary (see also Limpus and Chaloupka, 1997). The quasi-likelihood error function depends on the empirical mean-variance relationship resulting from the data (McCullagh and Nelder, 1989) and actually accounts for the potential correlated error that is intrinsic to data collected by mixed longitudinal studies. Cubic smooth splines are used to study the relationship between the dependent variable and a predictor variable by estimating the non-parametric functions of the predictors. An advantage of using cubic smoothing splines is that they reduce the effects of small sample size and outliers, highlighting the underlying curvilinear functional forms.

Covariate function plots for the GAM model fits were developed for each covariate. These plots can be used to evaluate the relationship between the response variable and the dependent variables by centring on the scale of the former and subtracting a weight mean to ensure valid pairwise confidence interval curves $(95 \%)$.

Model fit was described by a t-ratio test to estimate how much each covariate contributes to the overall 
TABLE 1. - Summary of parameter estimates of GAM (identity link, quasi-likelihood error term, cubic smoothing splines) fitted to Mediterranean loggerhead turtle growth rates. Null deviance: 100.72 null df: 37 , residual deviance: 64.351 , residual df: $24.995, R^{2}=0.36$.

\begin{tabular}{lcccccc}
\hline Parameter & $\begin{array}{c}\text { Asymptotic } \\
\text { Estimate }\end{array}$ & $\begin{array}{c}\text { Non-linear effects } \\
\text { SE }\end{array}$ & t-ratio & P & df & F \\
\hline Constant & 152.145 & 111.99 & 1.359 & & & \\
Mean year & -0.0731 & 0.0559 & -1.307 & ns & & \\
Mean size & -0.0516 & 0.0239 & -2.155 & $<0.05$ & 3 & 0.238 \\
Recapture interval & -0.0794 & 0.1327 & -0.598 & ns & \\
\hline
\end{tabular}

model fit and a non-parametric $F$ test estimated the nonlinearity of each covariate included in the model. A detailed description of the structure and application of GAM models can be found in Chaloupka and Limpus (1997) and Limpus and Chaloupka (1997).

On the basis of the resulting monotonic declining curve (see Results) it was assumed that in the observed size range growth can be described by a von Bertalanffy (1938) growth function and its parameters $L_{\infty}$ (the mean asymptotic carapace length) and $k$ (growth coefficient) were estimated by the program FiSAT II (Gayanilo et al., 2005) with Faben's method for the analysis of growth increment data (i.e. CMR).

The von Bertalanffy (1938) growth function in the form $L_{t}=L_{\infty}-\left(L_{\infty}-L_{0}\right) e^{(-k t)}$, where $L_{t}$ is the carapace length at age $t$, and $L_{0}$ is the initial carapace length, was used to estimate the time required by turtles to grow within the observed size range, thus avoiding extrapolation outside the range, which is one of the main concerns when one is using a von Bertalanffy growth function. $L_{0}$ was set as $35 \mathrm{~cm}$, which is considered as the lower bound of the observed size range: the minimum mean CCL was $36.8 \mathrm{~cm}$ and the minimum CCL at first release was $32.5 \mathrm{~cm}$.

\section{RESULTS}

Size at first release of the 38 turtles considered ranged from 32.5 to $82.0 \mathrm{~cm}$ CCL (mean $=57.9 ; \mathrm{SD}$ $=11.8$ ), while size at re-encounter ranged from 41.0 to $86.0 \mathrm{~cm} \mathrm{CCL}$ (mean $=65.4 ; \mathrm{SD}=11.4)$. Most of these turtles were probably immature, because the average female starts breeding at a size slightly smaller than the average size of nesting females (Limpus, 1990), which in the Mediterranean ranges from 66.5 to $84.7 \mathrm{~cm} \mathrm{CCL}$ (depending on the nesting site and year; Margaritoulis et al., 2003), and males appear to reach maturity around 75-80 cm CCL in the Mediterranean (Casale et al., 2005).

Turtles were re-encountered after 1.0-10.9 years (mean $=3.1 ; \mathrm{SD}=2.2)$ and their growth ranged from
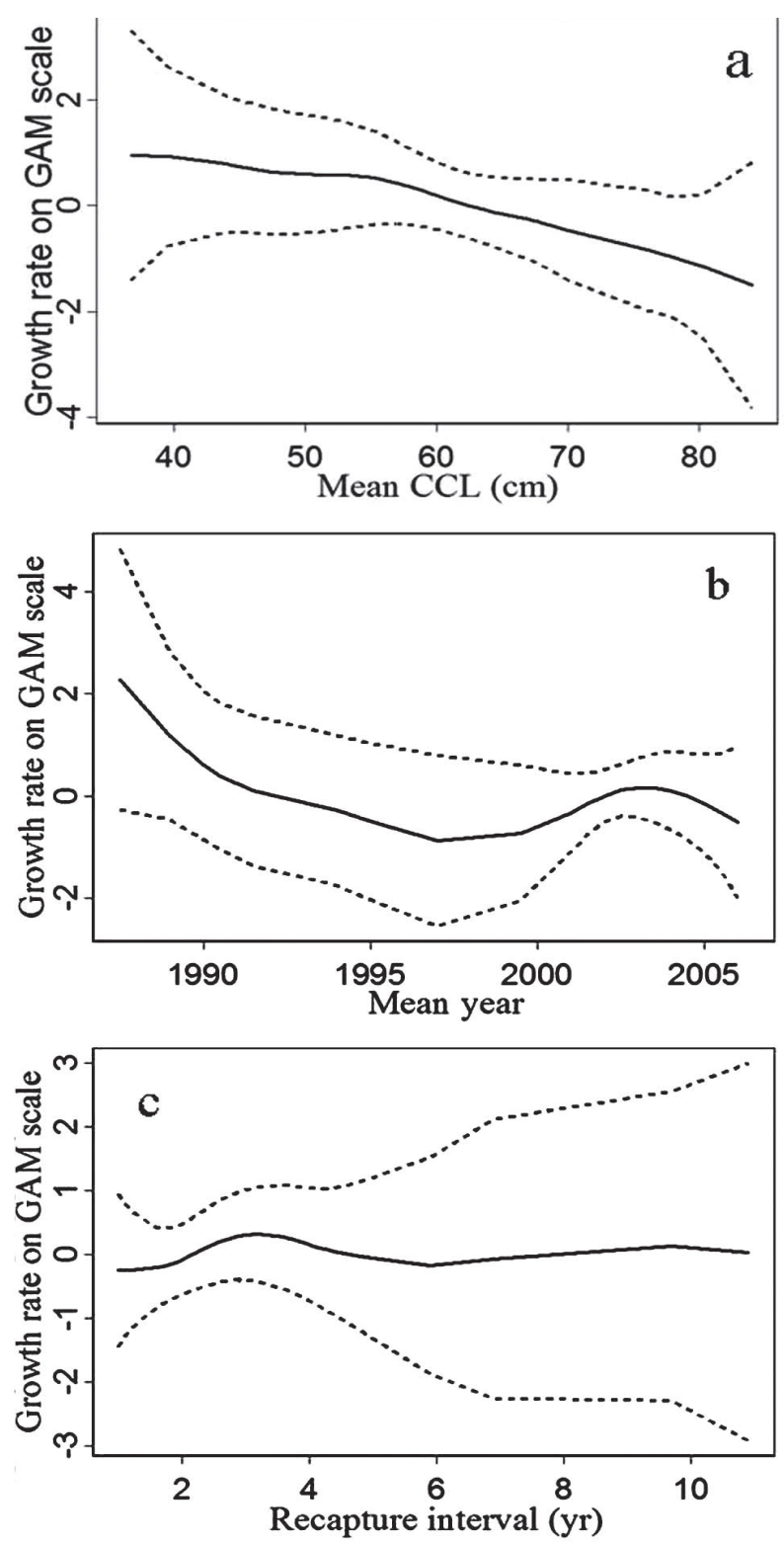

FIG. 1. - Graphical summary of the GAM analysis on growth covariates as summarised in Table 1 . The response variable (annual growth rate) is shown in the y-axis as a centred smooth function scale to ensure valid pointwise confidence bands (95\%). Covariates are shown on the $\mathrm{X}$-axis. (a) mean size of sizes at release and re-encounter, (b) year and (c) recapture intervals in years. Solid curves indicate the cubic smoothing splines fit for each covariate conditioned on all other covariates in the GAM fit; dashed curves are pointwise $95 \%$ confidence bands around these fits. 


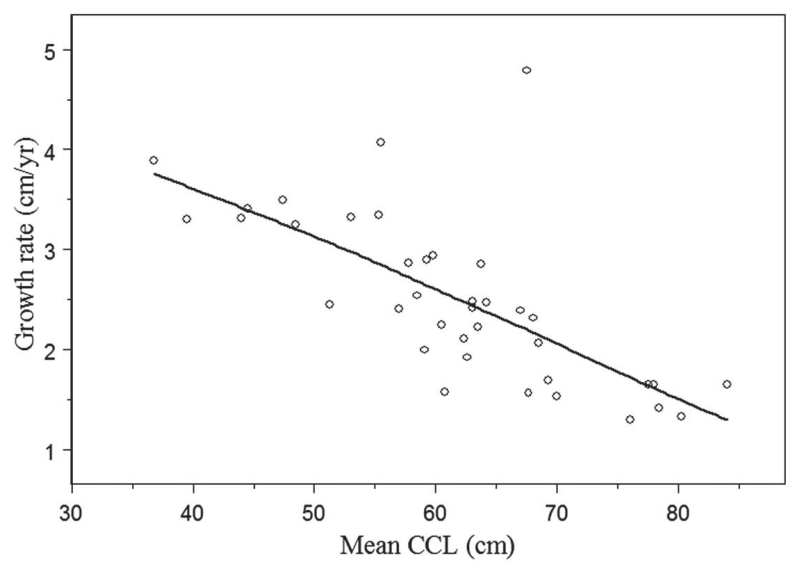

FIG. 2. - Estimated size-specific growth rate function for the Mediterranean loggerhead sea turtles produced by the GAM model fit. Open circles represent fitted values for the GAM model, solid curve represent the cubic-B smoothing spine fitted to those values. CCL: Curved Carapace Length.

0 to $5.97 \mathrm{~cm} / \mathrm{yr}$ (mean 2.5 ; SD: 1.7 ). Two turtles (70 and $78 \mathrm{~cm} \mathrm{CCL)} \mathrm{showed} \mathrm{no} \mathrm{growth} \mathrm{after} 1.7$ and 2.1 years.

The GAM regression model provided a fairly good fit $\left(\mathrm{R}^{2}=0.36\right.$; Table 1$)$ to the size-specific growth data and identified significant effects on growth rates in spite of the low sampling size and the great individual variability. However, the remaining variability indicates that some other factors not included in the model (e.g. individual, sex, age, and cohort) might affect growth rates as well. Among the three covariates investigated (mean size, mean year, and time interval), only mean size showed an effect on growth rate (Table 1; Fig 1a-c) and this effect showed no significant nonlinearity (Table 1; Fig 1a).

The estimated growth function was a monotonic curve, with maximum growth rates at smaller size classes and gradually decreasing to minimum values at larger size classes (Fig. 2). This monotonic curve

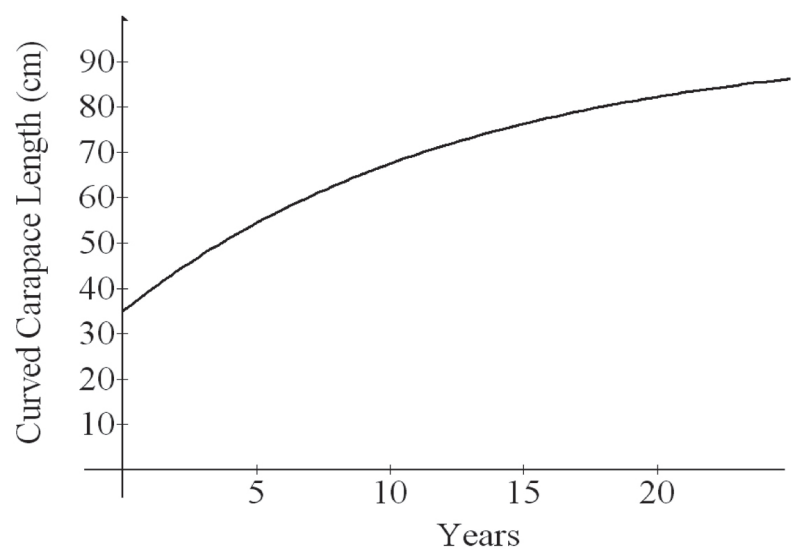

FIG. 3. - Age-specific growth function for the Mediterranean loggerheads generated by the von Bertalanffy model. with no spurt growth within the observed range supports the use of the von Bertalanffy function.

The von Bertalanffy growth parameters were estimated as $L_{\infty}=95.63 \mathrm{~cm} \mathrm{CCL}$, which is reasonably close to the maximum size of females nesting in the Mediterranean $(99 \mathrm{~cm}$ CCL; Margaritoulis et al., 2003 ), and $k=0.077 / \mathrm{yr}$. The von Bertalanffy model indicates that turtles would require about 9.5-22.3 years to grow from $35 \mathrm{~cm} \mathrm{CCL}$ (considered as the lower bound of the observed size range) to 66.5$84.7 \mathrm{~cm}$ CCL (range of means of nesting females observed in different nesting seasons and sites in the Mediterranean; Margaritoulis et al., 2003) (Fig. 3).

\section{DISCUSSION}

\section{Growth rate}

The results show a great variability in growth rates (Fig. 2) that could not be ascribed to the investigated covariates other than size. The two time parameters other than year (age and cohort) could not be investigated because of lack of such information on individual turtles, a common situation in this kind of study, but it may well play a role. However, non-time parameters such as individual variability may be good candidates for the cause of the observed growth-rate variability. For instance, a difference in growth rate between sexes has been reported (Chaloupka et al., 2004). Growth rates might also have genetic bases and vary among populations. The Mediterranean is known to be frequented by turtles, especially small juveniles, belonging to the Atlantic populations (Laurent et al., 1998; Carreras et al., 2006a; Casale et al., 2008) and this may be a source of variability. Another factor is probably spatial variability (e.g. food availability). In fact, a variety of different habitats can be found within a relatively short distance in the Mediterranean, and turtles, especially small ones, have been shown to move among distant areas (Casale et al., 2007). In such a situation, individuals frequenting, by chance or preference, different areas providing different trophic resources would be expected to show different growth rates (e.g. Diez and van Dam, 2002; Balazs and Chaloupka, 2004).

Growth rates showed a declining monotonic relation with size. Other studies reported either similar patterns (e.g. Bjorndal et al., 2000a,b) or non-monotonic growth curves (e.g. Seminoff et al., 
2002; Balazs and Chaloupka, 2004; Chaloupka and Limpus, 1997). However, the present results cannot exclude a nonmonotonic pattern. First, this lack of a significant non-linear effect may be due to a relative small sample size in smaller size classes $(<50 \mathrm{~cm})$, which have wide $95 \%$ confidence intervals (Fig. 1a). Second, mean size from long time intervals may confound the real pattern. Third, results concern only a part of the size range $(>35 \mathrm{~cm} \mathrm{CCL})$. Actually, when considered together, the present findings and the growth rates estimated for turtles $<30 \mathrm{~cm}$ CCL (Casale et al., in press) are compatible with a polyphasic pattern.

Although growth of adult turtles is considered to be negligible (Carr and Goodman, 1970), turtles of the present sample, which are in the range of the mean size of Mediterranean nesting females, showed relatively high growth rates and the growth rate pattern does not suggest a low asymptote in the observed range (Fig. 2). These findings are difficult to explain with just variability in maturity size, i.e. with rare individuals attaining maturity at larger sizes than the average (Limpus and Reed, 1985), and may have two main explanations. First, the sample includes a high proportion of turtles which mature at larger size than was thought on the basis of nesting data. The Mediterranean is known to be frequented by turtles belonging to the Atlantic populations, which do not reproduce in the basin and are thought to return to the Atlantic (Carreras et al., 2007). They are characterised by larger size at maturity than the Mediterranean populations (Dodd, 1988; Margaritoulis et al., 2003), but have not been observed in the basin at large size (the largest individual carrying the mtDNA haplotype endemic to the Atlantic was $65 \mathrm{~cm}$ CCL; Laurent et al. 1998). Thus, the large turtles observed with high growth rates may be Atlantic specimens, but this would mean that many of them remain in the Mediterranean much longer than is commonly thought. The second explanation is that the assumption that turtles almost stop growing at maturity is wrong. A similar puzzling finding of high growth rates in turtles of adult size has been reported for Chelonia mydas on the Pacific coast of Mexico (Seminoff et al., 2002), while growth of adult female leatherback turtles has recently been demonstrated in the pacific coast of Costa Rica (Price et al., 2006).

The growth rates observed in this study (Fig. 2) are similar to those from the Atlantic: Bjorndal et al. (2000a) reported comparable growth rates of 10 juvenile specimens (with mean CCL in the range $>30 \mathrm{~cm}$ ).

\section{Age at sexual maturity}

Mediterranean nesting females are much smaller than Atlantic ones (Margaritoulis et al., 2003). The reason for this is unclear; among several hypotheses, smaller size in the Mediterranean might be associated with shorter migrations or longer anthropogenic impact. As two extreme opposite patterns, this could be due either to a lower growth rate with similar age at maturity, or a shorter maturation period with a similar growth rate. Age at maturity may have important consequences for our knowledge of the dynamics of Mediterranean population and its capacity to respond to the relevant human impact in the area, since the longer the maturation time, the slower the population growth (e.g. see Heppell et al., 2003b).

The results indicate that to reach the mean size of Mediterranean nesting females from an initial size of $35 \mathrm{~cm} \mathrm{CCL}$, turtles would take about 9.5-22.3 years. Another study (Casale et al., in press) estimated that in the Mediterranean loggerhead turtles reach 27.9 $\mathrm{cm}$ CCL when 3.5 years old, with a growth rate of 3 $\mathrm{cm} / \mathrm{yr}$ in the last period. Assuming a growth rate of $3 \mathrm{~cm} /$ year (see also Fig. 2) in the gap between the two studies (27.9-35 cm CCL), turtles with a CCL of $35 \mathrm{~cm}$ might reasonably be six years old. Thus, age at maturity of Mediterranean loggerhead turtles is probably $16-28$ years. However, the average age is probably in the upper part of this range, since the smallest females are from Cyprus only, while the other nesting areas with more abundant populations (Greece, Turkey, Libya) have larger nesting females. In Greece, mean sizes are above $81.6 \mathrm{~cm} \mathrm{CCL}$, while in Turkey and Libya they are above $76 \mathrm{~cm} \mathrm{CCL}$ (Margaritoulis et al., 2003), corresponding to an age over 25.0 and 20.6 years respectively. Although there is great variability and uncertainty about age at maturity, Atlantic turtles are estimated to mature at over 30 years (Heppell et al., 2003a). If so, present results would suggest that Mediterranean loggerhead turtles mature at a younger age than Atlantic ones.

\section{ACKNOWLEDGEMENTS}

This study was made possible thanks to the invaluable efforts of many individuals: all the fishermen who collaborated in the three tagging projects of the University of Rome 1 "La Sapienza", WWF Italy, and ARCHE'; the students and volunteers who helped in the field work; and the central and local authorities. 
We are grateful to B. Lazar (Croatian Natural History Museum, Zagreb, Croatia) and G. De Metrio (Dept. of Animal Health and Well-Being, University of Bari) for providing two additional CMR records. We also thank two anonymous referees who provided useful comments on a first draft of this article.

\section{REFERENCES}

Argano, R., R. Basso, M. Cocco and G. Gerosa. - 1992. New data on loggerhead (Caretta caretta) movements within Mediterranean. Boll. Mus. Ist. Biol. Univ. Genova, 56-57: 137-163.

Balazs, G.H. and M. Chaloupka. - 2004. Thirty-year recovery trend in the once depleted Hawaiian green sea turtle stock. Biol. Conserv., 117(5): 491-498.

Bjorndal, K.A. and A.B. Bolten. - 1988. Growth rates of juvenile loggerheads, Caretta caretta, in the southern Bahamas. J. Herpetol., 22(4): 480-482.

Bjorndal, K.A., A. Bolten and H.R. Martins. - 2000a. Somatic growth model of juvenile loggerhead sea turtles Caretta caretta: duration of pelagic stage. Mar. Ecol. Prog. Ser., 202: 265-272.

Bjorndal, K.A., A.B. Bolten and M.Y. Chaloupka. - 2000b. Green turtle somatic growth model: evidence for density dependence. Ecol. Appl., 10(1): 269-282.

Bolten, A.B. - 1999. Techniques for measuring sea turtles. In: K.L. Eckert, K.A. Bjorndal, F.A. Abreu-Grobois and M. Donnelly (eds.), Research and Management Techniques for the Conservation of Sea Turtles, pp. 110-114. IUCN/SSC Marine Turtle Specialist Group Publication No. 4. Washington, DC

Carr, A. and D. Goodman. - 1970. Ecologic implications of size and growth in Chelonia. Copeia, 1970: 783-786.

Carreras, C., S. Pont, F. Maffucci, M. Pascual, A. Barcelo, F. Bentivegna, L. Cardona, F. Alegre, M. SanFelix, G. Fernandez and A. Aguilar. - 2006a. Genetic structuring of immature loggerhead sea turtles (Caretta caretta) in the Mediterranean Sea reflects water circulation patterns. Mar. Biol., 149: 1269-1279.

Carreras C., L. Cardona, A. Marco, M. Pascual, A. Aguilar, D Margaritoulis, A. Rees, J.J. Castillo, J. Tomás, J.A. Raga, G. Fernández, M. SanFelix, O. Turkozan, Y. Levy, A. Gasith, M Aureggi, M. Khalil, C. Rico and S. Roques. - 2006b. Degree of isolation of the Mediterranean nesting populations of the loggerhead sea turtle using nuclear markers. In: M. Frick, A. Panagopoulou, A.F. Rees and K. Williams (eds.), Book of abstracts, 26th Ann. Symp. Sea Turtle Biol. Conserv., p. 186. International Sea Turtle Society, Athens.

Carreras, C., M. Pascual, L. Cardona, A. Aguilar, D. Margaritoulis, A. Rees, O. Turkozan, Y. Levy, A. Gasith, M. Aureggi and M. Khalil. - 2007. The genetic structure of the loggerhead sea turtle (Caretta caretta) in the Mediterranean as revealed by nuclear and mitochondrial DNA and its conservation implications. Conserv. Genet., 8(4): 761-775.

Casale, P. - 2008. Incidental catch of marine turtles in the Mediterranean Sea: captures, mortality, priorities. WWF Italy, Rome.

Casale, P., D. Freggi, R. Basso and R. Argano. - 2005. Size at male puberty, sexing methods, and adult sex ratio in loggerhead turtles (Caretta caretta) from Italian waters investigated through tail measurements. Herpetol. J., 15: 145-148.

Casale, P., D. Freggi, R. Basso, C. Vallini and R. Argano. - 2007. A model of area fidelity, nomadism, and distribution patterns of loggerhead sea turtles (Caretta caretta) in the Mediterranean Sea. Mar. Biol., 152: 1039-1049.

Casale P., D. Freggi, P. Gratton, R. Argano and M. Oliverio. - 2008. Mitochondrial DNA reveals regional and interregional importance of the central Mediterranean African shelf for loggerhead sea turtles (Caretta caretta). Sci. Mar., 72(3): 541-548.

Casale, P., P. Pino d'Astore and R. Argano. - (in press). Age at size and growth rates of early juvenile loggerhead sea turtles (Caretta caretta) in the Mediterranean based on length frequency analysis. Herpetol. $J$.

Chaloupka, M., C.J. Limpus and J. Miller. - 2004. Green turtle somatic growth dynamics in a spatially disjunct Great Barrier
Reef metapopulation. Coral Reefs, 23(3): 325-335.

Chaloupka, M. and C.J. Limpus. - 1997. Robust statistical modeling of hawksbill sea turtle growth rates (Southern Great Barrier Reef). Mar. Ecol. Prog. Ser., 146(13): 1-8.

Chaloupka, M.Y. and J.A. Musick. - 1997. Age, growth, and population dynamics. In: P.L. Lutz and J.A. Musick (eds.), The Biology of Sea Turtles, pp. 233-276. CRC Marine Biology Series, CRC Press, Inc.: Boca Raton, London, New York, Washington D.C.

Diez, C.E. and R.P. van Dam. - 2002. Habitat effect on hawksbill turtle growth rates on feeding grounds at Mona and Monito Islands, Puerto Rico. Mar. Ecol. Prog. Ser., 234: 301-309.

Dodd, C.K. Jr. - 1988. Synopsis of the biological data on the loggerhead sea turtle Caretta caretta (Linnaeus 1758). U.S. Fish Wildl. Serv., Biol. Rep. 88(14). Washington, DC.

Gayanilo, F.C. Jr., P. Sparre and D. Pauly. - 2005. FAO-ICLARM Stock Assessment Tools II (FiSAT II). User's Guide. FAO Computerized Information Series (Fisheries). No. 8.

Hastie, T.J. and R.J. Tibshirani. - 1990. Generalized additive models. Monographs on statistics and applied probability, 43. Chapman and Hall, London

Heppell, S.S., M.L. Snover and L.B. Crowder. - 2003a. Sea turtle population ecology. In: P.L. Lutz, J.A Musick and J. Wyneken (eds.), The Biology of Sea Turtles. Volume II, pp. 275-306. CRC Marine Biology Series, CRC Press, Inc.: Boca Raton, London, New York, Washington D.C.

Heppell, S.S., L.B. Crowder, D.T. Crouse, S.P. Epperly and N.B. Frazer. - 2003b. Population Models for Atlantic Loggerheads: Past, Present, and Future. In: A.B. Bolten and B. Witherington (eds.), Loggerhead Sea Turtles, pp. 255-273. Smithsonian Institution Press, Washington, DC, USA.

Laurent, L., P. Casale, M.N. Bradai, B.J. Godley, G. Gerosa, A.C. Broderick, W. Schroth, B. Schierwater, A.M. Levy, D. Freggi, E.M. Abd El-Mawla, D.A. Hadoud, H.E. Gomati, M. Domingo, M. Hadjichristophorou, L. Kornaraky, F. Demirayak and Ch. Gautier. - 1998. Molecular resolution of marine turtle stock composition in fishery bycatch: a case study in the Mediterranean. Mol. Ecol., 7: 1529-1542.

Limpus, C.J. - 1990. Puberty and first breeding in Caretta caretta. In: T.H. Richardson, J.I. Richardson and M. Donnelly (compilers), Proc. 10th Ann. Works. Sea Turtle Biol. Conserv., pp. 81-83. NOAA Technical Memorandum NMFS-SEFC-278. Miami, FL.

Limpus, C.J. and P.C Reed. - 1985. The green turtle, Chelonia mydas, in Queensland: a preliminary description of the population structure in a coral reef feeding ground. In: G. Grigg, R. Shine and E. Ehmann (eds.), The biology of Australasian frogs and reptiles, pp. 47-52. Surrey Beatty \& Sons, Chipping Norton, Australia.

Limpus, C.J. and M. Chaloupka. - 1997. Nonparametric regression modeling of green sea turtle growth rates (Southern Great Barrier Reef). Mar. Ecol. Prog. Ser., 149(13): 23-34.

Margaritoulis, D., R. Argano, I. Baran, F. Bentivegna, M.N. Bradai, J.A. Caminas, P. Casale, G. De Metrio, A. Demetropoulos, G. Gerosa, B. Godley, J. Houghton, L. Laurent and B. Lazar. - 2003. Loggerhead turtles in the Mediterranean Sea: present knowledge and conservation perspectives. In: A.B. Bolten and B. Witherington (eds.), Loggerhead Sea Turtles, pp. 175-198. Smithsonian Institution Press, Washington, DC, USA.

Mazaris, A.D., O. Fiksen and Y.G. Matsinos. - 2005. Using an individual-based model for assessment of sea turtle population viability. Popul. Ecol., 47: 179-91.

McCullagh P. and J.A. Nelder. - 1989. Generalized linear models. Monographs on statistics and applied probability, 37. Chapman and Hall, London.

Price, E.R., B.P. Wallace, R.D. Reina, J.R. Spotila, F.V. Paladino, R. Piedra and E. Velez. - 2006. Size, growth, and reproductive output of adult female leatherback turtles Dermochelys coriacea. Endang. Species Res. 1: 41-48.

Seminoff, J.A., A. Resendiz, W.J. Nichols and T.T. Jones. - 2002. Growth rates of wild green turtles (Chelonia mydas) at a temperate foraging area in the Gulf of California, Mexico. Copeia, 2002(3): 610-617

Von Bertalanffy, L. - 1938. A quantitative theory of organic growth (inquiries on growth laws). Human Biol., 10(2): 181-213.

Scient. ed.: D. Oro.

Received September 22, 2008. Accepted December 22, 2008.

Published online May 19, 2009. 